\begin{tabular}{|r|r|}
\hline p-ISSN 1858-1048 \\
e-ISSN 2654-9247
\end{tabular}

\title{
KEPERCAYAAN, KEMUDAHAN PENGGUNAAN DAN ELECTRONIC WORD OF MOUTH TERHADAP MINAT BELI ONLINE
}

\author{
Oleh: \\ Muh. Ali Maskuri'), Ergo Nurpatria Kurniawan'), Mursida Kusuma Wardani'), Meli \\ Andriyani4) \\ Maskuriali@yahoo.co.id $\left.{ }^{1}\right)$, ergo.mustgo@gmail.com ${ }^{2}$,, idha_mkw@yahoo.com ${ }^{3)}$, my_odah@yahoo.com ${ }^{4)}$ \\ Sekolah Tinggi Ilmu Ekonomi IPWI Jakarta 1,2,3,4)
}

\begin{abstract}
ABSTRAK
Berkembangnya teknologi internet dan meningkatnya pengguna internet, membuat kegiatan perdaganganpun mulai mengalami perkembangan. Banyak pelaku bisnis yang menggunakan internet untuk melakukan promosi dan melakukan perdagangan, bisnis baru dalam dunia digital ini disebut dengan perdagangan elektronik (e-commerce). Tujuan yang diinginkan adalah Minat beli online dipengaruhi oleh kepercayaan, kemudahan penggunaan dan electronic word of mouth pada Tokopedia.

orang-orang yang pernah melakukan belanja online di Tokopedia atau situs belanja online lain digunakan sebagai sampel. Sampel yang digunakan sebanyak 96 orang yang dipilih menggunakan nonprobabilility sampling melalui kuesioner. Analisa regresi digunakan untuk teknik analisa dalam penelitian ini yaitu regresi linier sederhana dengan alat bantu software komputer SPSS 22.

Hasil penelitian ini menyatakan bahwa variabel independen yang paling berpengaruh terhadap variabel dependen adalah Electronic Word of Mouth (E_WOM) $(0,521)$, diikuti oleh kepercayaan konsumen $(0,421)$ dan yang terahir adalah kemudahan penggunaan $(0,209)$. Hasil menunjukan minat beli on line dipengaruhi oleh variabel kepercayaan, kemudahan penggunaan dan electronic word of mouth pada situs Tokopedia.
\end{abstract}

Kata kunci: kepercayaan, kemudahan penggunaan, electronic word of mouth, minat beli

\section{PENDAHULUAN}

Penggunaan internet telah menjadi sarana umum untuk orang beselancar di dunia maya yang terus berkembang pesat hingga saat ini. Internet dapat dijumpai dimana saja dan bagaimana masyarakat pengguna menggunakan untuk keperluan bisnis. Meskipun metode ini transaksi bisnis atau pertukaran telah mulai memenangkan hati pembeli Malaysia, elemen mempengaruhi kesediaan untuk membeli secara online masih belum diketahui. Oleh karena itu, tujuan dari penelitian ini adalah untuk menguji unsur yang niat pengaruh pembeli untuk membeli secara online (Azahari Jamaludin, 2013).

Yoon C Cho, 2015 mengatakan bahwa dengan menerapkan Technology AcceptanceModel, penelitian ini difokuskan pada menyelidiki faktorfaktor yang mempengaruhi perilaku pembelian online pelanggan. Hasil 
penelitian ini menunjukkan bahwa dirasakan kegunaan, persepsi kemudahan penggunaan, dan kepercayaan memiliki pengaruh yang signifikan secara statistik pada niat perilaku untuk berbelanja di Internet. Hal ini menunujkkan bahwa proses kemudahan penggunaan, kenikmatan berbelanja, pengalaman pembelian dan kepercayaan konsumen terhadap konsumen pembelian niat di situs belanja Bukalapak.com. (Prasetyo Agus Nurrahmanto, 2015) .

Informativeness dan keahlian sumber adalah prediktor yang memadai kegunaan eWOM. Selain itu, dirasakan persuasi, keahlian sumber, dan sumber kepercayaan significantly memprediksi kepercayaan dari eWOM berkaitan dengan SNSs. Ditemukan bahwa dirasakan kegunaan dan kredibilitas bersama-sama meningkatkan kemungkinan adopsi pesan eWOM, dan eWOM adopsi memiliki peran mediasi yang kuat di dalam fl Pengaruh kredibilitas eWOM dan kegunaan pada niat beli konsumen terhadap produk yang direkomendasikan pada SNSs. Sejak beberapa studi sebelumnya telah meneliti peran mediasi adopsi eWOM di dalam fl pengaruh anteseden pada niat beli konsumen, ini studi confirms peran mediasi kunci yang diberikan oleh adopsi eWOM pada hubungan antara kegunaan dan kredibilitas eWOM dan niat beli. Hasil kami juga harus mendorong pemasar untuk bekerja dengan SNSs untuk mengembangkan kampanye viral marketing, mendorong pelanggan untuk menyebarkan berguna dan kredibel $\mathrm{C} 2 \mathrm{C}$ eWOM untuk meningkatkan niat pembelian (Duong Hanh Tien et al, 2018).

Salah satu kemajuan teknologi informasi yang menarik adalah dengan munculnya internet. Internet adalah nama yang diberikan pada koleksi jaringan komunikasi komputer terbesar di dunia yang terdiri dari jaringan yang lebih kecil yang dibentuk oleh jaringan ARPANET yaitu suatu jaringan yang dibentuk oleh Pemerintah AS untuk kepentingan militer (Laudon ,2005)

Internet mulai dikenal di Indonesia sejak tahun 1990-an, dan terus berkembang hingga saat ini. Menurut
APJII (Asosiasi Penyelenggara Jasa Internet Indonesia) lembaga yang dapat memperkirakan pengguna internet, pengguna internet di Indonesia terus mengalami peningkatan dari tahun ke tahun. APJII memproyeksikan bahwa pada akhir tahun 2017 pengguna internet di Indonesia mencapai sekitar 143,26 juta penggunna dan diperkirakan akan terus meningkat karena diiringi kemajuan teknologi mobile yang semakin canggih dan juga terjangkau.

Perdagangan elektronik (ecommerce) menurut Laudon (2012) adalah the use of internet and the web to transactbusiness. Munculnya ecommerce ini, khususnya consumer-toconsumer (C2C) e-commerce membuat jual beli memasuki dimensi baru. Banyak dari para pelaku bisnis membuat sebuah perusahaan baru berbasis $\mathrm{C} 2 \mathrm{C}$ ecommerce, mereka membuat sebuah wadah sebagai tempat bertemunya penjual dan pembeli dalam dunia digital yang disebut dengan marketplace online atau situs jual beli online. E-commerce merupakan proses pembelian dan penjualan produk, jasa dan informasi yang dilakukan secara elektronik dengan memanfaatkan jaringan komputer yaitu internet (Handayani dan Purnama, 2013).

Tokopedia merupakan salah satu situs jual beli online terbesar di Indonesia. Sama seperti situs jual beli online lainnya yang berbasis $\mathrm{C} 2 \mathrm{C}$ (Consumer-to-Consumer), Tokopedia menyediakan sarana penjualan dari konsumen kepada konsumen dimanapun dan kapanpun dapat dengan mudah membuka toko online untuk melayani calon pembeli di seluruh Indonesia.

Seiring dengan terus berkembangnya bisnis e-commerce ini maka tingkat persainganpun semakin ketat. Salah satu masalah dalam penjualan online adalah sulitnya membangun kepercayaan pembeli. Berbelanja melalui internet mempunyai keunikan tersendiri dibandingkan dengan berbelanja secara tradisional, yaitu dari segi ketidakpastian, anonim, minimnya kontrol dan potensi dalam 
pengambilan kesempatan (Sonja et al dalam Prasetyo, 2015).

Penelitian sebelumnya yang tentang Pengaruh Persepsi Keamanan, Kemudahan Bertransaksi, Kepercayaan Terhadap Toko Dan Pengalaman Berbelanja Terhadap Minat Beli Secara Online Pada Situs Jual Beli Tokopedia.Com" oleh Fachrizi Alwafi dan Rizal Hadi Magnadi (2016) menyatakan bahwa kepercayaan berpengaruh positif terhadap minat beli secara online pada situs Tokopedia.com. Dalam penelitian lain yang berjudul Pengaruh Kepercayaan Dan Risiko Terhadap Minat Beli Belanja Online oleh Rosian Anawar dan Wijaya Adidarma (2016) menyatakan bahwa kepercayaan memiliki pengaruh positif terhadap minat beli belanja online.

Kemudahan

penggunaan merupakan tingkatan seseorang yang percaya bahwa tidak dibutuhkan banyak usahan dalam menjalankan sebuah sistem karena kemudahannya (Davis dalam Shinta, 2016). Perilaku seseorang dipengaruhi oleh sistem yang dinilai mudah digunakan secara otomatis (Succi dan Walter dalam Prasetyo, 2015).

Penelitian sebelumnya oleh Prasetyo Agus Nurrahmanto (2015) dalam artikelnya yang berjudul Pengaruh Kemudahan Penggunaan, Kenikmatan Berbelanja, Pengaalaman Berbelanja dan Kepercayaan Konsumen Terhadap Minat Beli Konsumen pada Situs Jual Beli Online Bukalapak.com menghasilkan kesimpulan bahwa kemudahan penggunaan berpengaruh positif terhadap minat beli secara online pada situs Bukalapak.com. Kharisma Rizki H (2015) dalam artikelnya yang berjudul Pengaruh Kemudahan dan Kualitas Informasi Terhadap Minat dan Keputusan Pembelian Secara Online menghasilkan kesimpulan bahwa kemudahan berpengaruh signifikan terhadap minat beli secara online.

Sebelum membeli biasanya konsumen akan mencari informasi terlebih dahulu mngenai produk yang akan dibelinya. Konsumen lebih sering mencari informasi melalui media elektronik seperti ulasan atau komentarkomentar (Electronic Word-of-Mouth) yang ada di media elektronik tersebut.
Electronic Word-of-Mouth (e-WOM) adalah serangkaian pernyataan yang dibuat dan digunakan oleh konsumen aktual, potensial atau konsumen sebelumnya mengenai produk atau perusahaan dimana informasi ini tersedia bagi orang-orang atau institusi melalui internet (Thurau et al, 2004:42).

Hal itu dikarenakan konsumen merasa lebih percaya terhadap mereka yang sudah pernah melakukan pembelian dari pada promosi langsung yang dilakukan oleh pemasar. Konsumen akan lebih mudah terpengaruh oleh rekomendasi orang lain yang sudah merasakan manfaat produk dari pada janji yang ditawarkan pemasar.

Dengan adanya kepuasan pengalaman yang dirasakan oleh konsumen hal ini akan mendorong konsumen untuk kembali meggunakan Tokopedia sebagai media jual beli online. Pendapat ini didukung oleh penelitian Bintarti at al (2017) dalam artikelnya yang berjudul A Study of Revisit Intention: Experiential Quality and Image of Muara Beting Tourism Site on Bekasi District, yang terbit pada European Research Studies Journal, dengan kesimpulan penelitian bahwa kepuasan konsumen dipengaruhi oleh kualitas pengalaman dan gambar situs pariwisata, niat revisit dipengaruhi oleh kepuasan pengalaman tetapi citra situs pariwisata statistik tidak terbukti mempengaruhi niat revisit.

\section{TUJUAN PENELITIAN}

Tujuan dari penelitian pada mahasiswa Program Studi Manajemen STIE Pelita Bangsa angkatan 2014 yaitu tentang minat beli yang dipengaruhi oleh variabel tingkat kepercayaan, kemudahan penggunaan dan electronic word of mouth pada media online Tokopedia.

\section{TELAAH LITERATUR DAN PENGEMBANGAN HIPOTESIS Kepercayaan}

Kepercayaan pada awalnya hanya dikaji dalam bidang psikologi, karena kepercayaan berhubungan dengan sikap 
seseorang. Namun saat ini kepercayaan telah dikaji dalam berbagai bidang seperti sosiologi, pemasaran dan juga dalam konteks organisasional. Kepercayaan tidak hanya dapat diberikan kepada seseorang tetapi juga sebuah objek. Menurut Kramer dalam Ling (2010) kepercayaan merupakan sebuah masalah yang kompleks, karena seorang individu tidak mengetahui pasti motif dan niat individu lain terhadap dirinya.

Di dalam e-commerce kepercayaan menjadi bagian penting untuk mengubah pengunjung menjadi pembeli. Ketika melakukan belanja online, pembeli bergantung kepada janji yang diberikan oleh penjual. Misalnya, pembeli tidak akan tahu apakah produk yang dipesan akan sesuai dengan yang diinginkan, pembeli juga harus percaya bahwa informasi pribadi yang diberikan kepada penjual tidak akan di salah gunakan dan apakah transaksi yang dilakukan aman dari penipuan.

Menurut Yousafzai dalam Rahmawati (2013) setidaknya terdapat enam definsi kepercayaan yang relevan dengan e-commerce, diantaranya adalah:

1. Rotter (1967) mendefinisikan kepercayaan sebagai sebuah keyakinan bahwa kata atau janji seseorang dapat dipercaya dan seseorang akan memenuhi kewajibannya dalam sebuah hubungan pertukaran.

2. Morgan dan Hunt (1994) mendefinisikan bahwa kepercayaan akan terjadi apabila seseorang memiliki kepercayaan diri dalam sebuah pertukaran dengan mitra yang memiliki integritas dan dapat dipercaya.

3. Mayer et al. (1995) mendefinisikan kepercayaan adalah kemauan seseorang untuk peka terhadap tindakan orang lain berdasarkan pada harapan bahwa orang lain akan melakukan tindakan tertentu pada orang yang mempercayainya.

4. Rousseau et al, (1998) mendefinisikan kepercayaan adalah wilayah psikologis yang merupakan perhatian untuk menerima apa adanya berdasarkan harapan terhadap perhatian atau perilaku baik dari orang lain.

5. Ba dan Pavlou (2002) mendefinisikan kepercayaan adalah penilaian hubungan seseorang dengan orang lain yang akan melakukan transaksi tertentu menurut harapan orang kepercayaanya dalam suatu lingkungan yang penuh ketidakpastian.

Menurut Verhagen dan Willemijin dalam Prasetyo (2016) menyatakan ada tiga indikator dalam kepercayaan konsumen yaitu:

1. Situs dapat diandalkan untuk berbelanja online.

2. Situs memiliki reputasi yang baik.

3. Situs memberikan keamanan dalam bertransaksi.

\section{Kemudahan Penggunaan}

Menurut (Davis dalam Shinta 2016) kemudahan penggunaan merupakan tingkatan seseorang yang percaya bahwa tidak dibutuhkan banyak usahan dalam menjalankan sebuah sistem karena kemudahannya. Kemudahan penggunaan suatu website menjadi pertimbangan konsumen sebelum melakukan belanja online. Meskipun belanja online memiliki banyak manfaat, namun kerumitan dalam berinteraksi dengan medianya dalam hal ini adalah bagian e-commerce jual beli online, bisa menjadi sesuatu yang membingungkan untuk pengguna. Haubl dan Trifts (dalam Selly dan Harry 2016) mengatakan bahwa teknologi yang digunakan situs belanja online yaitu internet, berpotensi untuk mengurangi biaya pencarian dan evaluasi alternatif-alternatif dan dapat meningkatkan ketertarikan pengguna website terhadap produk-produk yang dijual. Oleh karena itu, kemudahan penggunaan suatu website perlu diperhatikan.

Kemudahan penggunaan suatu situs belanja online berhubungan dengan mudah atau tidaknya situs digunakan oleh calon pembeli. Jika komponenkomponen pada website rumit dan sulit dipelajari, pengguna website cenderung mengurungkan niatnya dalam berbelanja online. Kerumitan penggunaan situs belanja online menurut Ramayah dan 
Ignatius (2005) dipengaruhi beberapa faktor seperti lamanya waktu untuk membuka situs tersebut, buruknya rancangan tampilan situs, dan peletakan menu yang tidak rapih. Jika penggunaan situs ternyata lebih rumit dibandingkan manfaat yang diperoleh, maka pengguna berpotensi akan lebih memilih berbelanja secara konvensional. Namun jika situs lebih mudah digunakan dan memberikan manfaat, calon pembeli akan menggunakan situs tersebut untuk berbelanja online.

Faktor-faktor tersebut dapat menjadi hambatan saat seseorang menggunakan suatu website yang berakibat mengurangi persepsi pengguna tentang kemudahan penggunaan website tersebut, hal ini memungkinkan pengguna untuk memunculkan sikap negatif terhadap situs tersebut. Sikap negatif ini akan berpengaruh kepada minat beli pengguna. Succi dan Walter dalam Selly dan Harry (2016 Perilaku seseorang itu karena adanya sistem yang dianggap memudahkan dalam pengaplikasiannya tentu saja membawa dampak bagi seseorang untuk meggunakannya. Media penjualan dan pembelia online dapat dikatakan baik jika situs tersebut menyediakan petunjuk jelas alur bertransaksi, mulai dari pemesanan, pembayaran, pengisian formulir, hingga produk maupun jasa sampai ke konsumen. Media penjual dan pembelian online tidak hanya harus menarik secara teknis, tetapi juga harus mudah dalam penggunaannya agar memberikan dorongan motivasi terhadap penggunanya untuk melakukan berbelanja online disana.

Davis dalam Prasetyo (2016) memberikan beberapa indikator dari kemudahan penggunaan yang antara lain:

1. Situs mudah di akses.

2. Situs mudah dipelajari.

3. Situs mudah digunakan.

\section{Electronic Word of Mouth (E -WOM)}

Menurut Thurau et al (2014:42) EWOM merupakan kalimat yang dibuat dan diucapkan oleh konsumen saat ini atau konsumen sebelumnya mengenai produk atau perusahaan dimana informasi ini tersedia bagi orang-orang ataupun institusi melalui media internet.

Menurut Cheung dan Lee (2012) ada beberapa faktor yang paling signifikan dalam mendorong E-WOM yaitu rasa memiliki, reputasi dan kebersediaan untuk membantu. E-WOM menjadi sebuah tempat yang sangat penting untuk konsumen memberikan opininya dan dianggap lebih efektif dibandingkan WOM (Word of Mouth) karena tingkat aksesibilitas dan jangkauannya yang lebih luas daripada WOM tradisional yang bermedia offline (Jalilva, 2012)

Menurut (Goyette dan Richard dalam Putri S 2018) E-WOM di bagi kedalam tiga dimensi yaitu:

1. Intensity.

2. Valence of opinion.

3. Content.

Berdasarkan pada penelitian Jalilvand dan Samiei (2012) terdapat beberapa ukuran-ukuran yang dilakukan konsumen tentang kalimat word of mouth diantaranya sebagai berikut:

1. Membaca ulasan online produk konsumen lain.

2. Mengumpulkan informasi dari review produk konsumen melalui internet.

3. Berkonsultasi secara online.

4. Perasaan khawatir apabila seseorang tidak membaca ulasan online sebelum melakukan pembelian.

5. Peningnkatan rasa percaya diri setelah membaca ulasan online.

\section{Minat Beli}

Menurut Kinnear dan Taylor (dalam Adi,2013) minat beli merupakan tahap kecenderungan responden untuk bertindak sebelum keputusan membeli benar-benar dilaksanakan, sedangkan menurut Simamora (2002) minat beli adalah sesuatu yang pribadi dan berhubungan dengan sikap individu yang berminat pada suatu objek akan mempunyai kekuatan atau dorongan untuk melakukan serangkaian tingkahlaku untuk mendekati atau mendapatkan objek tersebut. Dari pengertian diatas dapat disimpulkan bahwa minat beli adalah suatu sikap dari konsumen untuk bertindak sebelum 
melakuka $\mathrm{n}$ pembelian terhadap sebuah produk.

Minat beli diperoleh melalui proses belajar dan proses pemikiran yang membentuk persepsi. Minat beli menciptakan suatu motivasi terhadap pikiran konsumen, yang pada akhirnya ketika konsumen harus memenuhi kebutuhannya maka akan mengaktualisasikan apayang ada di dalam pikirannya. Minat beli diperkuat oleh adanya dorongan perasaan serta emosionalisasi seseorang tentang produk atau jasa yang mereka beli sehingga mereka akan puas. (Kinner Taylor dalam Adi, 2013).

Lucas dan Britt (1951) mengatakan bahwa terdapat aspek-aspek dalam miant beli, antara lain:

1. Perhatian (attention) adanya perhatian yang besar terhadap produk yang diinginkan oleh konsumen.

2. Ketertarikan (interest) setelah adanya perhatian maka akan timbul rasa untuk memiliki produk tersebut.

3. Keinginan (desire) berlanjut dari ketertarikan akan timbul rasa untuk memiliki produk tersebut.

4. Keyakinan (conviction) setelah itu akan timbul keyakinan pada diri konsumen terhadap produk tersebut yang menimbulkan tindakan akhir, keputusan (action) untuk memperolehnya melalui tindakan membeli.

Hipotesis merupakan jawaban yang sifatnya sementara atas rumusan masalah yang kebenarannta akan di uji dalam pengujian hipotesis (Sugiyono, 2008: 306). Berdasarkan perumusan masalah, tinjauan pustaka dan tujun penelitian, maka dapat ditarik hipotesis sementara dari penelitian ini, yaitu:

$\mathrm{H} 1$ : Semakin tinggi tingkat kepercayaan konsumen pada situs jual beli Tokopedia maka minat beli secara online pada Tokopedia akan meningkat.

H2: Semakin tinggi persepsi kemudahan penggunaan yang dirasakan konsumen maka minat beli online pada Tokopedia akan semakin meningkat.

H3: Semakin baik Electronic Word of Mouth (E-WOM) pada situs jual beli Tokopedia maka minat beli online pada Tokopedia akan semakin meningkat.

Berdasarkan hipotesa tersebut maka dapat diterjemahkan dalam desaian penelitian sebagai berikut:

Gambar 1

Desain Penelitian

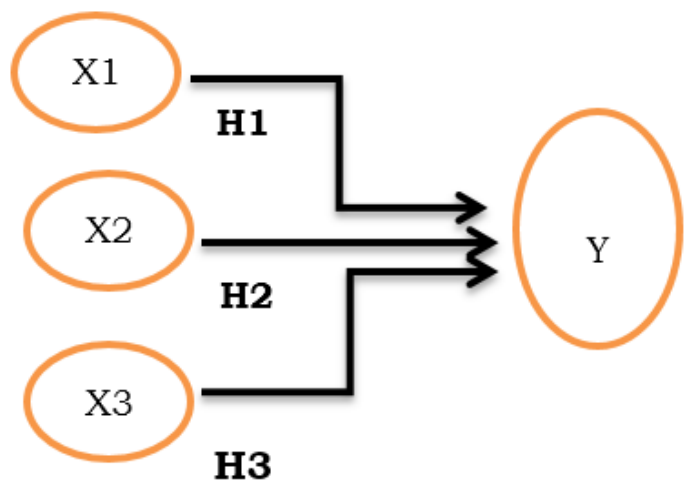

\section{METODE PENELITIAN}

Penelitian ini menggunakan pendekatan deskriptif kuantitatif yang digunakan adalah survei yaitu untuk pengumpulan data primer pada informasi yang diperoleh dari responden. Pengumpulan data dilakukan menggunakan instrumen kuesioner atau angket. Berdasarkan eksplanasinya, tergolong sebagai penelitian untuk mengetahui sebab akibat. Hubungan atau pengaruh variabel kepercayaan (X1), kemudahan penggunaan (X2) dan electronic word of mouth (X3) terhadap variabel terikat minat beli $(\mathrm{Y})$.

\section{Sampel Penelitian}

Mahasiswa Prodi Manajemen STIE Pelita Bangsa angkatan 2014 senagai populasi dalam penelitian ini yaitu para pengguna belanja on line dalam periode tertentu yaitu sejumlah 1.943, tanpa membedakan jenis kelamin, dari jumlah popupasi tersebut dapat dijelaskan bahwa jumlah Laki-laki adalah 886 dan Perempuan 1.057. 
Dalam mengabil sampel peneliti melakukan dengan metode nonprobability sampling, yaitu adanya kesempatan yang tidak sama untuk dipilih bagi anggota populasi menjadi sampel. Besarnya sample yang digunakan dalam penelitian ini ditentukan dengan menggunakan rumus Slovin.

Sampel dalam penelitian ini adalah Mahasiswa Prodi Manajemen STIE Pelita Bangsa angkatan 2014 yang pernah melakukan belanja online di Tokopedia atau situs belanja online lain. Sampel yang digunakan sebanyak 96 orang yang dipilih menggunakan nonprobabilility sampling melalui kuesioner.

\section{Operasionalisasi Variabel}

Definsi oprasional

variabel merupakan suatu definisi yang diberikan kepada suatu variabel dengan memberi arti atau menspesifikasikan kegiatan atau membenarkan suatu oprasional yang diperlukan untuk mengukur variabel tersebut (Sugiyono, 2004). Adapun variabel penelitian dan definisi oprasionalnya di jelaskan dalam tabel sebagai berikut:

Tabel 1

Operasionalisasi Variabel

\begin{tabular}{|c|c|}
\hline Variabel & Indikator \\
\hline Kepercayaan(X1) & Dapat diandalkan \\
Fachrizi Alwafi & Reputasi baik \\
dan Rizal Hari & Keamanan \\
(2016) & Mudah diakses \\
& Mudah dipelajari \\
& Mudah digunakan \\
\hline Kemudahan & Mudah diakses \\
Penggunaan & Mudah dipelajari \\
(X2) Prasetyo & Mudah digunakan \\
Nur Rahmanto & \\
(2016) & \\
\hline E-WOM (X3) & Membaca review (ulasan) \\
Jalilvand dan & Konsultasi konsumen lain \\
Saimei (2012) & Mengumpulkan informasi \\
& Khawatir jika tidak melihat review \\
Minat beli online & Percaya diri membeli produk \\
(Y) Qonita & Tertarik membeli \\
Lutfiah dan & Bersedia Merekomendasikan \\
Citra Kusuma & Tertarik mereview \\
Dewi (2016) & \\
\hline
\end{tabular}

\section{Metode Analisis}

Metode analisis kuantitatif ini dilakukan terhadap data yang diperoleh dari hasil jawaban kuisioner dan digunakan untuk menganalisis data yang berbentuk angka dan perhitungan menggunakan metode statistik. Data tersebut harus diklasifikasikan dalam kategori tertentu dengan menggunakan tabel-tabel tertentu untuk memudahkan dalam menganalisis. Analisa regresi liner sederhana dengan alat bantu software komputer SPSS 22 yang digunakan dalam penelitian ini.

\section{HASIL DAN PEMBAHASAN Hasil Penelitian}

Tokopedia adalah salah satu perusahaan yang bergerak di bidang ecommerce yang memungkinkan setiap pebisnis di Indonesia mengelola bisnis mereka secara online dengan mudah dan gratis. Tokopedia yang didirikan oleh William Tanuwijaya dan Leontinus Alpha Edison berdiri pada 6 Februari 2009 tetapi diresmikan kepada publik pada 17 agustus 2009, di tahun 2009 itu PT. Indonusa yang memberikan pendanaan awal kepada Tokopedia.

Seiring perkembangan dari Tokopedia selama kurun waktu 1 tahun banyak perusahaan yang memberikan dana permodalan seperti East Venture (2010), Cyber Agent Venture (2011), Netprice (2012), dan SoftBank Venture Korea (2013). Pada Oktober 2014, Tokopedia terpilih sebagai perusahaan teknologi pertama di Asia Tenggara yang menerima investasi sebesar USD 100 juta atau sekitar Rp 1,2 triliun dari Sequoia Capital dan SoftBank Internet dan Media Inc (SIMI) (Sumber:www.Wikipedia.com, 2015).

Tokopedia merupakan salah satu mall online di Indonesia yang mengusung model bisnis marketplace. Berkat peranannya dalam mengembangkan bisnis online di Indonesia, PT Tokopedia berhasil meraih penghargaan Marketeers of The Year 2014 untuk sektor ECommerce pada acara Markplus Conference yang digelar oleh Markplus Inc pada tanggal 11 Desember 2014.

Tokopedia memiliki penjual yang terus tumbuh sebesar $30 \%$ setiap bulannya. Produk aktif yang ada di Tokopedia berjumlah 3,3 juta produk dimana sekitar 2 juta produk terjual setiap bulannya (www.Techinasia.com, 
2014). Untuk memudahkan penjual dan pembeli dalam melakukan jual beli, Tokopedia menyediakan 21 kategori besar seperti pakaian, kecantikan, otomotif, olahraga dan kategori-kategori lainnya. Sistem pembayaran di Tokopedia menggunakan sistem rekening bersama atau escrow. Dalam hal ini, Tokopedia berperan sebagai pihak ketiga yang menengahi antara penjual dan pembeli, sehingga dapat mengurangi terjadinya tindak penipuan. Hingga awal tahun 2015, terdapat lima metode pembayaran yang dapat digunakan untuk bertransaksi di Tokopedia oleh pembeli dan penjual, antara lain Saldo Tokopedia, Transfer Bank serta pembayaran instan seperti Mandiri ClickPay, Mandiri E-Cash dan BCA KlikPay.

\section{Hasil analisa apakah kepercayaan yang baik akan berpengaruh terhadap minat beli online pada Tokopedia}

Uji korelasi dan regresi dugunakan untuk mengetahui hubungan kepercayaan (X1) dengan minat beli online (Y) dan pengaruh kepercayaan (X1) terhadap minat beli online $(\mathrm{Y})$ dalam analisis linier sederhana, kita dapat melihat dari nilai $\mathrm{R}$ dan $\mathrm{R}$ square yang terdapat pada output SPSS bagian Model Summary.

Tabel 2

Hasil Uji Korelasi dan Regresi

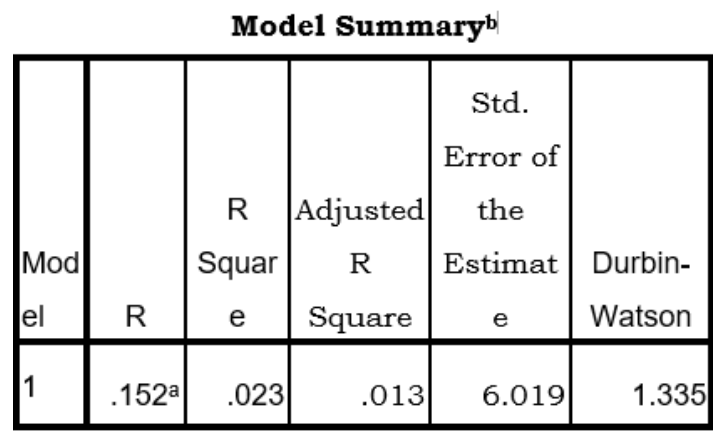

a. Predictors: (Constant),

Kepercayaan

b. Dependent Variable:

Minat Beli

bahwa:

Hasil output di atas diketahui
- $\quad$ Nilai $R=0,152$. nilai ini memiliki arti bahwa kepercayaan (X1) memiliki hubungan terhadap minat beli online (Y) pada Mahasiswa Prodi Manajemen STIE Pelita Bangsa angkatan 2014. sebesar 15,\%.

- Nilai $R$ square $=0,023$ nilai ini memiliki arti bahwa pengaruh kepercayaan (X1) terhadap minat beli online $(\mathrm{Y})$ pada Mahasiswa Prodi Manajemen STIE Pelita Bangsa angkatan 2014. adalah sebesar 23\% sedangkan $77 \%$ minat beli $(\mathrm{Y})$ dipengaruhi oleh variabel lain yang tidak diteliti dalam penelitian ini.

- Berdasarkan hasil coeficients diketahui nilai thitung sebesar 5,783 lebih besar dari > 1,494 sehingga dapat disimpulkan bahwa Ho ditolak dan Ha diterima, yang berarti bahwa "Ada pengaruh kepercayaan (X1) terhadap minat beli online $(\mathrm{Y})$.

Rumus persamaan regresi linier sederhana adalah $\mathrm{Y}=\mathrm{a}+\mathrm{bX}$. Maka model persamaan regresinya $\mathrm{Y}=$ $28,603+0,098 X 1$. Persamaan tersebut bermakna jika X1 adalah nol, maka minat beli sebesar 28,603, dan jika dipengaruhi oleh variabel kepercayaan, minat beli akan naik sebesar 0,098.

Hasil analisa apakah kemudahan penggunaan aplikasi yang baik akan mempengaruhi minat beli online pada Tokopedia

Uji korelasi dan regresi digunakan untuk mengetahui hubungan kemudahan penggunaan (X2) terhadap minat beli online $(\mathrm{Y})$ dan pengaruh kemudahan penggunaan (X2) terhadap minat beli online $(\mathrm{Y})$ dalam analisis linier sederhana, kita dapat melihat dari nilai $\mathrm{R}$ dan $R$ square yang terdapat pada output SPSS bagian Model Summary.

Hasil output analisis dapat diketahui bahwa:

Nilai $R$ square $=0,210$ nilai ini memiliki arti bahwa kepercayaan (X) memiliki hubungan terhadap minat beli online $(\mathrm{Y})$ pada Mahasiswa Prodi Manajemen STIE Pelita Bangsa angkatan 2014. sebesar $21 \%$.

Nilai $R=0,459$, nilai ini memiliki arti bahwa kemudahan penggunaan (X2) 
kemudahan penggunaan (X2) terhadap minat beli online $(\mathrm{Y})$ pada Mahasiswa Prodi Manajemen STIE Pelita Bangsa angkatan 2014. adalah sebesar $21 \%$ sedangkan $94,9 \%$ minat beli (Y) dipengaruhi oleh variabel lain dan tidak sedang diteliti.

Hasil coeficients diketahui nilai thitung sebesar 4.274 lebih besar dari > 1,166 sehingga dapat disimpulkan bahwa bahwa "Ada pengaruh kemudahan penggunaan (X2) terhadap minat beli (Y).

- Rumus persamaan regresi linier sederhana adalah $\mathrm{Y}=\mathrm{a}+\mathrm{bX}$ maka model persamaan regresinya $\mathrm{Y}=$ $37,808+0,209 X 2$. Persamaan tersebut bermakna jika X2 adalah nol, maka minat beli sebesar 37,808 , dan jika dipengaruhi oleh variabel kemudahan penggunaan minat beli akan naik sebesar 0,209.

Tabel 3

Hasil Uji Korelasi dan Regresi Variabel Kemudahan Penggunaan (X2) Terhadap Minat Beli (Y)

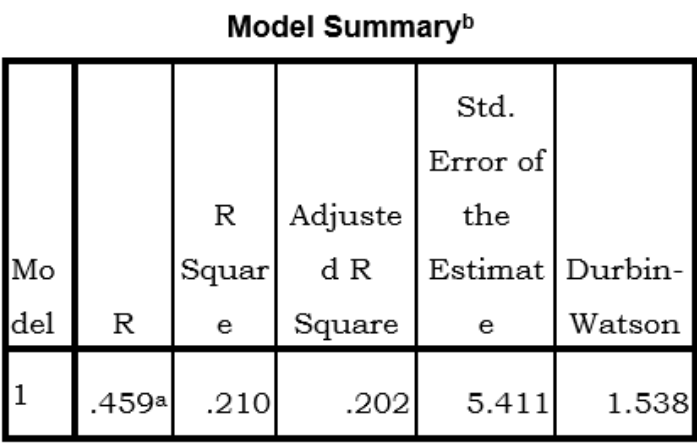

a. Predictors: (Constant),

Kemudahan

b. Dependent Variable:

Minat Beli

Hasil analisa apakah E_WOM yang baik akan mempengaruhi minat beli online pada Tokopedia

Uji korelasi dan regresi digunakan untuk mengetahui hubungan E_WOM (X3) dengan minat beli online (Y) dan pengaruh E_WOM terhadap minat beli online (Y), dalam analisis linier sederhana, kita dapat melihat dari nilai $\mathrm{R}$ dan nilai $R$ square yang terdapat pada output SPSS bagian Model Summary.
Tabel 4

Hasil Uji Korelasi dan Regresi Variabel E_WOM (X3) Terhadap Minat Beli (Y)

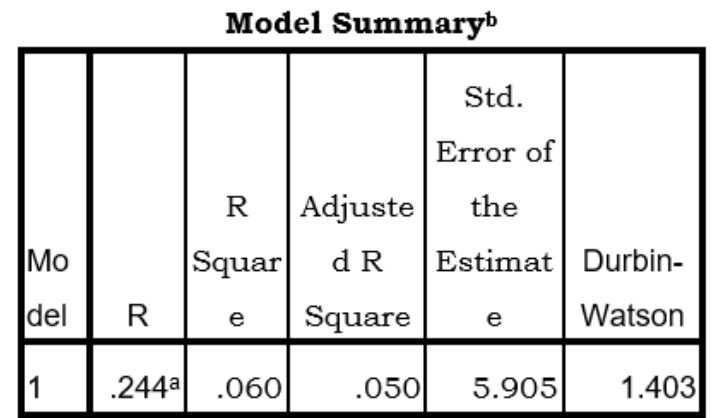

a. Predictors: (Constant),

\section{EWOM}

b. Dependent Variable:

Minat Beli

Hasil output analisis di atas diketahui bahwa:

Nilai $R=0,244$, nilai ini memiliki arti bahwa E_WOM (X3) memiliki hubungan dengan minat beli online (Y) pada Mahasiswa Prodi Manajemen STIE Pelita Bangsa angkatan 2014 sebesar 24.4\%.

Nilai $R$ square $=0,060$, nilai ini memiliki arti bahwa pengaruh E_WOM (X3) terhadap minat beli online (Y) pada Mahasiswa Prodi Manajemen STIE Pelita Bangsa angkatan 2014 adalah sebesar $24,4 \%$ sedangkan $75,6 \%$ dipengaruhi oleh variabel lain yang tidak diteliti dalam penelitian ini.

Berdasarkan hasil coeficients diketahui nilai thitung sebesar 0.549 lebih besar dari > 1,166 sehingga dapat disimpulkan bahwa Ho ditolak dan Ha diterima, yang berarti bahwa "Ada pengaruh E_WOM (X3) terhadap minat beli (Y). Rumus persamaan regresi linier sederhana adalah $\mathrm{Y}=\mathrm{a}+\mathrm{bX}$, maka model persamaan regresinya $\mathrm{Y}=28.603+0.071 \mathrm{X} 3$. Persamaan tersebut bermakna jika X3 adalah nol, maka minat beli sebesar 28.603, dan jika dipengaruhi oleh E_WOM minat beli akan naik sebesar 0,071 


\section{Pembahasan}

Berdasarkan hasil analisis tentang kepercayaan yang baik akan berpengaruh terhadap minat beli online pada Tokopedia menyatakan bahwa kepercayaan berpengaruh terhadap minat beli pada Mahasisswa Prodi Manajemen STIE Pelita Bangsa angkatan 2014 yaitu dengan Nilai $R$ square $=0,262$ nilai ini memiliki arti bahwa pengaruh kepercayaan (X1) terhadap minat beli online (Y) adalah sebesar 26,2\% sedangkan $73,8 \%$ minat beli $(\mathrm{Y})$ dipengaruhi oleh variabel lain yang tidak diteliti dalam penelitian ini. Hal ini sejalan dengan Penelitian sebelumnya yang berjudul " Pengaruh Persepsi Keamanan, Kemudahan Bertransaksi, Kepercayaan Terhadap Toko Dan Pengalaman Berbelanja Terhadap Minat Beli Secara Online Pada Situs Jual Beli Tokopedia.Com" oleh Fachrizi Alwafi dan Rizal Hadi Magnadi yang terbit pada Diponegoro Journal of Management Volume.5 No.2 tahun 2016 menyatakan bahwa kepercayaan berpengaruh positif terhadap minat beli secara online pada situs Tokopedia.com. Dalam penelitian lain yang berjudul "Pengaruh Kepercayaan Dan Risiko Terhadap Minat Beli Belanja Online" oleh Rosian Anawar dan Wijaya Adidarma yang terbit pada Jurnal Manajemen dan Bisnis Sriwijaya Volume !4 No.2 tahun 2016 menyatakan bahwa kepercayaan berpengaruh positif terhadap minat beli belanja online.

Tingkat kepercayaan yang hanya memberikan prosentase $26,2 \%$ terhadap minat beli konsumen pada situs jual online tokopedia merupakan hal yang harus terus digali sebagai pengambilan keputusan dalam manajemen, karena tingkat kepercayaan konsumen yang masih dibawah lima puluh persen menggambarkan bahwa kepercayaan konsumen masih jauh dari ekspektasi penjualan yang diharapkan.

Hasil analisa apakah kemudahan penggunaan aplikasi yang baik akan mempengaruhi minat beli online pada Tokopedia menyatakan bahwa kemudahan penggunaan berpengaruh terhadap minat beli pada Mahasiswa Prodi Manajemen STIE Pelita Bangsa angkatan 2014 Nilai $R$ square $=0,053$ nilai ini memiliki arti bahwa pengaruh kemudahan penggunaan (X2) terhadap minat beli online $(\mathrm{Y})$ adalah sebesar $5,3 \%$ sedangkan $94,7 \%$ minat beli (Y) dipengaruhi oleh variabel lain yang tidak diteliti dalam penelitian ini. Hasil ini sejalan dengan Penelitian sebelumnya oleh Prasetyo Agus Nurrahmanto dalam artikelnya yang berjudul Pengaruh Kemudahan Penggunaan, Kenikmatan Berbelanja, Pengaalaman Berbelanja dan Kepercayaan Konsumen Terhadap Minat Beli Konsumen di Situs Jual Beli Online Bukalapak.com yang terbit pada Diponegoro Journal Of Management Volume.4 No.2 periode tahun 2015 menghasilkan kesimpulan bahwa kemudahan penggunaan berpengaruh positif terhadap minat beli secara online pada situs Bukalapak.com. Kharisma Rizki $\mathrm{H}$ dalam artikelnya yang berjudul Pengarh Kemudahan dan Kualitas Informasi Terhadap Minat dan Keputusan Pembelian Secara Online yang terbit pada Jurnal Administrasi Bisnis (JAB) Volume.28 Nomor.1 periode tahun 2015 menghasilkan kesimpulan bahwa variabel kemudahan berpengaruh signifikan terhadap minat beli secara online.

Kemudahan penggunaan aplikasi terhadap minat beli konsumen yang hanya sebesar 5,3\% tentu saja sebagai gambaran bahwa konsumen belum familiar dalam menggunakan aplikasi pada smartphone yang dimiliki. Oleh karena itu tokopedia sebagai penyedia situs jual online harus terus berupaya memberikan informasi cara penggunaan aplikasi serta sebagai ajang pembelajaran kepada masyarakat tentang pentingnya aplikasi yang memudahkan masyarakat dalam kehidupan terutama dalam melakukan belanja online sseiring dengan industri 4.0.

Hasil analisa apakah E_WOM yang baik akan mempengaruhi minat beli online pada Tokopedia menyatakan bahwa E_wom berpengaruh terhadap minat beli pada Mahasiswa Prodi Manajemen STIE Pelita Bangsa angkatan 2014 Nilai $R$ square $=0,295$, nilai ini memiliki arti bahwa pengaruh E_WOM (X3) terhadap minat beli online (Y) adalah 
sebesar 29,5\% sedangkan $70,5 \%$ dipengaruhi oleh variabel lain yang tidak diteliti dalam penelitian ini. Hasil ini sejalan dengan penelitian Bintarti at al dalam artikelnya yang berjudul A Study of Revisit Intention: Experiential Quality and Image of Muara Beting Tourism Site on Bekasi District, yang terbit pada European Research Studies Journal Vol.XX Issue 2A periode tahun 2017, dengan kesimpulan penelitian bahwa kepuasan konsumen dipengaruhi oleh kualitas pengalaman dan gambar situs pariwisata, niat revisit dipengaruhi oleh kepuasan pengalaman tetapi citra situs pariwisata statistik tidak terbukti mempengaruhi niat revisit.

E-wom terhadap minat beli pada situs belanja online tokopedia hanya sebesar 29,5\% yang berarti bahwa kekuatan elektronic word of mouth belum begitu efektif, sehingga perlu terus ditingkatkan sebagai sarana dalam berpromosi untuk terus meningkatkan penjualan.

\section{KESIMPULAN}

\section{Simpulan}

1.Kepercayaan yang baik akan mempengaruhi minat beli, dalam hal ini pada konsumen Tokopedia. Terjadi pengaruh kepercayaan terhadap minat beli online sebesar $26,2 \%$. Pengaruh yang relatif rendah ini disebabkan oleh kurangnya kepercayaan konsumen tehadap Tokopedia.

2 Kemudahan penggunaan website dan aplikasi yang baik pada sebuah situs jual beli online akan mempengaruhi minat beli konsumen, dalam hal ini adalah konsumen Tokopedia. Kemudahan penggunaan berpengaruh terhadap minat beli online sebesar 5,3\%. Pengaruh yang sangat rendah ini disebabkan oleh website dan aplikasi Tokopedia sering mengalami error.

3 Electronic Word Of Mouth (E_WOM) yang baik akan mempengaruhi minat beli, dalam hal ini adalah konsumen Tokopedia. E_WOM berpengaruh terhadap minat beli online sebesar 29,5\%. Pengaruh yang relatif rendah ini desebabkan oleh kurangnya minat konsumen untuk membaca E_WOM sebelum melakukan pembelian menggunakan situs Tokopedia.

\section{Saran}

1. Perusahan harus meningkatkan tingkat kepercayaan konsumen baik dalam pelayanan maupun barang agar minat beli bertambah. Walaupun pengaruhnya relatif rendah E-WOM harus di tingkatkan agar minat beli konsumen meningkat.

2. website merupakan alat yang sangat mudah untuk mengetahui barang yang diinginkan konsumen oleh karena itu perusahaan harus selalu aplikasinya untuk mengembangkan minat beli konsumen.

3. Bagi peneliti selanjutnya diharapkan dapat mengkaji lebih dalam tentang minat beli dengan variabel-variabel lainnya yang lebih variatif seperti produk yang dijual, kualitas pelayanan, harga, fitur pelayanan pada tokopedia maupun media jual beli online lainnya.

\section{DAFTAR PUSTAKA}

Adi Triatma dan Fitriati Akmalia. (2012). Pengaruh Trust dan Penerimaan Teknologi Terhadap Minat Konsumen Dalam Pembelian Online, Kajian Bisnis dan Manajemen Vol.13 No.1

Azahari Jamaludin. (2013) Investigating The Relationship Between Trust and Intention To Purchase Online, Business and Management Horizns Vol.1 No.1

Duong Hanh Tien et al., (2018). Examining The Influence Of Customer-to customer Electronic Word Of Mouth On Purchase Intention In Social Networking Sites, Asia Pascific Management Review Vol. 1

Fachrizi Alwafi dan Rizal Hari Magnadi., (2016). Kepercayaan Terhadap Toko Dan Pengalaman Berbelanja Terhadap Minat Beli Secara Online, 
Diponegoro Journal of Management Vol. 5 No. 2

Haekal Azwar dan Widjajanta B. (2016). Pengaruh Kepercayaan dan Persepsi Risiko Terhadap Minat Membeli Secara Online Pada Pengunjung Website Classifieds di Indonesia, Journal of Business Management and Enterpreneurship Education Vol.1 No.1

Harris, L. C. dan Goode, M. H. (2010). Online Servicecapes, Trust, and Purchase Intention. Journal of Service Marketing. Vol 24 No. 3.

Jalillvand, M,R dan Samiei, N. (2012). The Effect of Electronic Word Of Mouth on Brand Image and Purchase Intention: an empirical Study In The Automobile Industry an Iran, Marketing Intelegence \& Planning, Vol. 30, Iss: 4 pp. $460-$ 467

Kharisma Rizki H. (2015). Pengaruh Kemudahan Dan Kualitas Informasi Terhadap Minat dan Keputusan Pembelian Secara Online, Jurnal Administrasi Bisnis (JAB) Vol.28 No.1.

Laudon, Kenneth C. and Carol Guercio Traver. (2012). E-commerce 2012: business. technology. Society, 8th ed. Harlow: Pearson

Prasetyo Agus Nurrahmanto. (2015). Pengaruh Kemudahan Penggunaan, Kenikmatan Berbelanja Pengalaman Berbelanja, dan Kepercayaan Konsumen Terhadap Minat Beli Konsumen di Situs Jual Beli Online Bukalapak,com, Diponegoro Journal of Management Vol.4 No.2

Qonita Lutfiah dan Citra Kusuma Dewi. (2016) Pengaruh Perilaku E-WOM Terhadap Online Purchase Intention Pada Produk Online Shop Khayna, e-Proceeding of Management Vol.3 No. 2
Rosian Anwar dan Wijaya Adidarma., (2016). Pengaruh Kepercayaan dan Risiko Terhadap Minat Beli Online, Management dan Bisnis Sriwijaya Vol.14 No.2

Selli Nisrina Faradila dan Harry Soesanto. (2016) Analisis Pengaruh Persepsi Kemudahan Penggunaan dan Persepsi Manfaat terhadap Minat Beli dengan Kepercayaan Sebagai Variabel Intervening, Diponegoro Journal of Management Vol.5 No.1

Shinta Ayuningrum. (2016) Pengaruh Kemudahan Penggunaan, Pengalaman Sebelumnya, Kepercayaan Konsumen dan Persepsi Harga Terhadap Minat Beli Dalam Transaksi Belanja Online, Diponegoro Journal Of Management Vol.5 No.2

Sri Rahmi Putri dan Rizki Amalia. (2018) Pengaruh E-WOM Terhadap Citra Perusahaan Dan Dampaknya Terhadap Minat Beli Konsumen Pada Situs Online Shopee.id, Jurnal Ilmiah Mahasiswa ekonomi Manajemen Vol.3 No.2.

Surya Bintarti dan Ergo Nurpatria Kurniawan. (2017) A Study of Revisit Intention: Experiential Quality and Image of Muara Beting Tourism Site In Bekasi District, European Research Studies Journal Volume XX, Issue 2A,

Yoon C Cho., (2015). Ekploring Faktors That Affect Usefulness, Ease of Use, Trust and Purchase Intention In The Online Environment, International Journal of Management And Information System Vol.19 No.1 